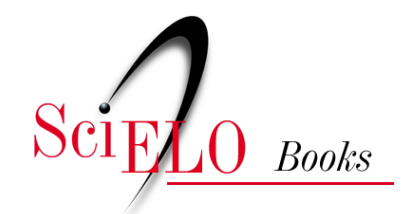

\title{
8. Infância e literatura
}

entre conceitos, palavras e imagens

\author{
Patrícia Corsino
}

\section{SciELO Books / SciELO Livros / SciELO Libros}

CORSINO, P. Infância e literatura: entre conceitos, palavras e imagens. In: SILVA, M.C., and BERTOLETTI, E.N.M., orgs. Literatura, leitura e educação (online). Rio de Janeiro: EDUERJ, 2017, pp. 207-230. Pesquisa em educação/ Práticas de leitura e escrita series. ISBN 978-85-7511-497-1. Available from: doi: 10.7476/9788575114971.0009. Also available in ePUB from: http://books.scielo.org/id/5gg44/epub/silva-9788575114971.epub

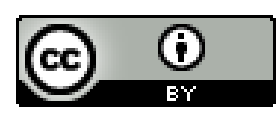

All the contents of this work, except where otherwise noted, is licensed under a Creative Commons Attribution 4.0 International license.

Todo o conteúdo deste trabalho, exceto quando houver ressalva, é publicado sob a licença Creative Commons Atribição $\underline{4.0}$.

Todo el contenido de esta obra, excepto donde se indique lo contrario, está bajo licencia de la licencia $\underline{\text { Creative Commons }}$ Reconocimento 4.0. 


\title{
8 \\ Infância e literatura: entre conceitos, palavras e imagen ${ }^{1}$
}

\author{
Patrícia Corsino
}

\begin{abstract}
[...] tudo é uma Literatura só. A dificuldade está em delimitar o que se considera como especialmente no âmbito infantil. São as crianças, na verdade, que o delimitam, com sua preferência. Costuma-se classificar como Literatura Infantil o que para elas se escreve. Seria mais acertado, talvez, assim classificar o que elas leem com utilidade e prazer. Não haveria, pois, uma Literatura Infantil a priori, mas a posteriori.
\end{abstract}

Cecília Meireles

Cecília Meireles, nos anos I950, questiona-se sobre o que poderia ser delimitado como literatura infantil. Propóe, assim, que o limite fosse dado pelas próprias crianças. Coloca, pois, nas crianças a liberdade de escolha. E isso acaba por interpelar os adultos diante da grande produção editorial voltada ao público infantil. $\mathrm{O}$ que seria literatura infantil? $\mathrm{O}$ que se pode considerar literatura? A literatura como arte vale-se de limites etários definidos? Haveria uma arte infantil?

Este artigo tem por objetivo refletir sobre infância e literatura na perspectiva de compreender a literatura infantil como arte e o livro infantil contemporâneo como espaço de articulação entre três campos: a arte da palavra/literatura, as artes visuais e a arte de design gráfico editorial.

\footnotetext{
I. Texto publicado na revista Teias, v. I6, n. 40, 20I5, Proped, UERJ. Disponível em: http://www. periodicos.proped.pro. Atualizado para este livro.
} 
Inicialmente, discutem-se os conceitos de infância e literatura, tomando como pressuposto o fato de que são historicamente produzidos e que a literatura infantil está em articulação com ambos os conceitos. Em um segundo momento, aborda literatura como arte e sua especificidade, trazendo o livro Raposa, de Margaret Wild e Ron Brooks, para dialogar com as seis propostas de Italo Calvino (1990) e o direito à literatura defendido por Candido (20II). Finaliza refletindo sobre a consistência de que uma literatura-arte pode dar sentido à própria existência.

\section{I Infância e literatura}

Infância e literatura são dois conceitos que foram inventados e reinventados ao longo do tempo, variando conforme a época, o lugar, os grupos sociais e seus valores. A literatura adjetivada como infantil é produzida no seio de uma cultura que define o que é ou năo literatura e também o que é ou não infantil ou próprio das/para as crianças.

A infância como uma categoria social é uma construção da modernidade. O que hoje entendemos como infância é um conceito que foi historicamente elaborado no mundo ocidental. Sarmento (20II) aponta quatro eixos estruturantes desse processo: i) a família nuclear, que, gradativamente, foi substituindo os outros agrupamentos familiares e foi se constituindo como um lugar de vinculação e pertença afetiva da criança; ii) a escola pública, criada no século XVIII, que se constituiu como um espaço institucional de crianças; iii) a construção de um conjunto de saberes institucionalizados sobre a "criança normal", que institui a ideia de criança como ser biopsicológico em processo de maturação e crescimento; iv) a administração simbólica, com a definição implícita e explícita de regras de inclusão, interdição, compulsão e reconhecimento das crianças. Assim, "o conjunto de injunçóes decorren- 
tes desses quatro pilares associados contribuiu desde há cerca de dois séculos e meio para consignar à criança um lugar social próprio, cujo desenho e cuja topografia correspondem à representação social dominante da infância” (p. 586). As crianças e a infância passaram a ser objeto de estudo de diferentes campos científicos, os quais foram aprofundando e ampliando os conhecimentos, ao lhes conferirem cientificidade.

Assim, no final do século XIX e no início do século XX, em toda parte do mundo ocidental, a infância era tanto um princípio social como um fato social (Postman, 1999, p.65), mas os conhecimentos começaram a ser sistematizados sob a lógica de construção do homem moderno, cujo "programa do esclarecimento era o desencantamento do mundo e cuja meta era dissolver os mitos e substituir a imaginação pelo saber" (Adorno e Horkeimer, 1985, p.19). A ciência, vista como verdade, teria a responsabilidade de explicar, organizar e catalogar o "real" e o "ser" em sua totalidade. A ciência e a racionalidade trouxeram a ideia de progresso como domínio do homem sobre a natureza, de evolução, de causa e efeito, de linearidade temporal, de controle e previsibilidade. Nesse projeto, a preocupação inicial com a educação das crianças teve por objetivo a construção do homem de amanhã, cuja maturidade seria identificada com a chegada à razão. A moralização e a disciplinarização impostas às crianças por pais e mestres faziam parte do projeto de abreviar o tempo da ignorância e apressar uma etapa da vida vista como menor, transitória e passageira.

$\mathrm{Na}$ perspectiva do progresso, o desenvolvimento humano foi concebido como uma sucessão de etapas ou estágios. A noção de desenvolvimento assume características próximas e derivadas da noção biológica de evolução, ou seja, da transformação de formas de se comportar e de pensar ao longo de um tempo linear e cumulativo, em que o homem adulto é o ponto de chegada. Ao descrever e organizar o desenvolvimento infantil em etapas, perío- 
dos ou fases, esse enfoque mostra cientificamente o processo de maturação da criança. O elenco de características próprias de cada momento torna-se, então, o parâmetro para organizar os conteúdos e as atividades consideradas próprias para cada faixa etária ou série escolar, enquadrar as crianças em comportamentos esperados, bem como avaliá-las e classificá-las segundo as etapas que já percorreram ou não.

Com um lugar social constituído, a infância passa a ter produçôes culturais distintas das dos adultos, e essas também passam a se valer dos estudos sobre o desenvolvimento infantil para atender a um público cada vez mais setorizado. Livros, brinquedos, filmes, entre outros, são produzidos e recomendados para determinada faixa etária ou série escolar, como se a infância fosse um conceito abstrato, genérico e universal, e como se a idade das crianças, em que pesem os contextos culturais, étnicos, religiosos e classes sociais, fosse uma categoria homogênea. As crianças são descontextualizadas de suas condiçôes sócio-históricas e culturais e afetivo-volitivas, tornando-se um nicho de mercado cada vez mais promissor. Souza (1996) adverte para esse processo crescente, que coloca a criança a serviço das imposiçóes de uma racionalidade "modeladora das formas específicas de subjetividade, cuja matriz é a situação histórica e social do homem moderno, submerso nas exigências de um ideal de sujeito produtivo e consumidor" (p. 46).

Para Castro (2013, p.I7), a cronologia do curso da vida torna-se um aspecto relevante, especialmente nas sociedades industriais modernas, em que a ordenação dos momentos da biografia direciona as oportunidades de participação dos indivíduos no mundo do trabalho, e a faixa etária serviria para a elaboração de um conjunto de normas de comportamento, com vistas a definir seu lugar social. Nesse cenário, a concepção de criança apresentou-se como uma fase de preparaçáo para a vida produtiva, determinan- 
do "um dever-ser desses sujeitos como indivíduos ainda não prontos, imaturos e ainda não socializados para participar integralmente da vida em sociedade" (Idem, ibidem). Afirma também:

Assim, a idade constituiu não apenas o índice que serviu para denotar a diferenciação [entre a infância e a vida adulta], mas o princípio temporal que a organiza. Ainda que se critique o uso essencialista dessas noções, as definiçóes sobre o que é ser criança permanecem até hoje atreladas à lógica evolutiva/diferencialista do curso da vida humana, principalmente se considerarmos o seu uso nos campos do direito e da educação. Mesmo admitindo-se deslocamentos em relação à concepção linear, cumulativa e progressista do ciclo da vida humana, parece difícil abrir mão da noção de preparação enraizada na percepção das novas geraçôes como "novatos" que chegam ao mundo que a eles preexiste (Idem, pp. 17-8).

Walter Benjamin (I993a e I993b) critica a concepção evolucionista de história como um tempo contínuo que caminha irremediavelmente para o futuro, que, em nome do progresso, descarta o passado, considerando-o velho ou obsoleto. Ao analisar criticamente a modernidade, relaciona o progresso e o desenvolvimento ao empobrecimento da experiência humana e à alienaçáo da linguagem.

Nessa perspectiva, Benjamin (I993b) traz outras possibilidades para se pensarem o tempo histórico e também as crianças. Em seus escritos "Rua de mão única", "Infância berlinense" e "Imagem e pensamento", não se limita a trazer recordaçôes de sua infância, mas, ao dar voz ao menino, traz a forma como ele via e sentia o mundo, falando também de um momento histórico e de uma sociedade. Nesse contexto, tal objetividade permite ao leitor o despertar de sua própria infância, quebrando-se, nessa rememoração, a ideia de tempo linear e ampliando-se o sentido 
de coletividade. O menino Walter fala de si, de seu momento histórico e de sua inserção social e cultural, trazendo uma história que é, ao mesmo tempo, individual e coletiva, história que pode ser continuada e ressignificada dentro de cada um de nós a partir da experiência de ser criança. História que também continua na experiência de ser criança em diferentes tempos e espaços. Os textos e fragmentos do autor, como uma mônada que contém na parte a totalidade, dáo voz à criança totalmente inserida na história, integrante da cultura e produtora de cultura. Benjamin, assim, recupera o mundo da cultura dos pais e, ao mesmo tempo, recupera a maneira de ver da criança, sua sensibilidade, seus hábitos, desejos, afetos e valores, evidenciando a agência ${ }^{2}$ infantil com toda a sua competência e a capacidade de agir e transformar.

Esse deslocamento na forma de pensar a infância antecipa o que vem sendo reivindicado pelos estudos contemporâneos, especialmente os da sociologia da infância, que trazem a noção de competência como distintiva de uma nova posição da criança no mundo, caracterizando-se pela capacidade de "co-construção da própria infância, como também da sociedade. Esse paradigma da competência faz das crianças agentes sociais plenos, cujo agir modifica as estruturas sociais em que se encontram, dando-lhes outros sentidos (Castro, 2013, p. I8).

Ainda que o paradigma da competência e da agência infantil busque seu espaço nas sociedades contemporâneas, como Castro elucida, parece difícil, ainda hoje, abrir mão da ideia de preparo das crianças. Náo se pode afirmar um consenso sobre essas concepçôes e que elas sejam universalmente aceitas. Assim, coexistem diferentes concepçôes de crianças e infâncias, que se apresentam, com frequência, de forma contraditória nos tempos e espaços em

2 Corsaro (20II) considera agentes aqueles que produzem a própria cultura, enquanto, simultaneamente, contribuem para a produção da sociedade, enquanto o termo agência [agency] diz respeito à ação de um agente e à açấo coletiva articulada com as transformaçōes sociais. 
que as crianças circulam, nos produtos e nos artefatos que portam e consomem, nos serviços e instituiçóes a elas direcionados. Desse modo, tanto a produçáo de literatura infantil como as formas de os adultos lerem para e com as crianças vão oscilando entre paradigmas distintos.

Também o conceito de literatura tem-se apresentado de formas diversas ao longo da história. Compagnon (2009), ao indagar o que seria literatura, chama a atenção para o fato de que o termo literatura data do início do século XIX. Anteriormente, literatura eram as inscriçóes, a escritura, a erudição ou o conhecimento das letras, o equivalente a cultura. No entanto, no sentido moderno de literatura, compreendem-se o romance, o teatro e a poesia, retornando-se à tríade pós-aristotélica dos gêneros épico, dramático e lírico. E, nessa veia, o critério de valor e a ideia de cânone, de grandes escritores, passaram a identificar a literatura com a literatura culta, excluindo tudo que fosse literatura popular, mas, como o sistema é dinâmico e cada nova obra movimenta o todo, operam-se novas configuraçóes e rearranjos da tradiçáo como totalidade. Assim, Compagnon argumenta que, após o estreitamento da literatura do século XIX, no século seguinte uma parte dos territórios perdidos foi novamente incorporada, e o termo literatura passou a ter novamente uma extensão mais ou menos vasta "dos clássicos escolares à história em quadrinhos, sendo difícil justificar sua ampliação contemporânea. O critério de valor que inclui tal texto não é em si mesmo literário nem teórico, mas ético, social, ideológico, de qualquer forma extraliterário" (Idem, p. 34).

Eagleton (2003), ao propor a mesma indagaçáo, questiona a ideia de literatura como uma categoria objetiva. Refuta a concepção de literatura como uma escrita imaginativa, como uma forma especial de linguagem em contraste com a linguagem comum, como algo sem finalidade prática imediata, trazendo também os julgamentos de valor como ponto fundamental para defini-la. Em 
outras palavras, valores que se referem não apenas ao gosto particular, mas também aos pressupostos pelos quais certos grupos sociais exercem e mantêm o poder sobre outros. Nessa perspectiva, considerar um texto literário ou não literário significa assumir um ponto de vista partilhado por um grupo que, por sua vez, tem suas concepçóes ideologicamente sustentadas.

É ainda Compagnon (20I2) que identifica quatro explicaçóes sobre o valor dado à literatura ao longo da história: i) na perspectiva clássica, a literatura seria um meio de instruir deleitando; ii) na perspectiva iluminista, a literatura seria um remédio para libertar os indivíduos de sua sujeição às autoridades, contestar a submissão ao poder e também um antídoto para a fragmentação da experiência subjetiva; iii) em um terceiro movimento, a literatura seria um remédio, mas não mais para os males da sociedade, e sim para a inadequação da língua, tornando os sujeitos mais inteligentes, por ensiná-los a não serem enganados pela língua: "Só a literatura trapaceando com a língua, trapaceando a língua, salvava a língua do poder da servidão" ( $\mathrm{p}$. 50, citando Barthes); iv) em um quarto momento, ocorre uma recusa a qualquer poder da literatura, que passa a ser entendida como um passatempo, "respiro" que estaria fora de compromisso instrumental ou de suplência - pedagógica, ideológica ou linguística. Assim, esses quatro movimentos situados pelo autor também coexistem e não se pode afirmar que sua adesão seja universal. Entretanto, apresentam concepçóes que conferiram e conferem - à literatura lugares ou valores sociais partilhados. Ocorrem permanências e recusas de posição.

A literatura infantil surge na injunção dos pilares que sustentaram a constituição da infância como uma categoria social. Aliando-se à família nuclear e à escola, tornou-se um caminho de moralização e ensino, lugar fértil para instruir as crianças divertindo. Os registros de contos de tradição oral, os quais eram exemplares 
não apenas para as crianças, foram os primeiros textos selecionados como leitura para e pelas crianças.

Para Benjamin (I993a), contudo, os contos de fadas, mesmo com cunho moralizante, podem ser considerados os primeiros conselheiros das crianças, por terem uma característica que os distingue dos textos meramente educativos: a cumplicidade da natureza com o homem e sua libertação do pesadelo mítico. É justamente essa possibilidade de o ouvinte/leitor dos contos de fadas vencer o mundo místico com astúcia e coragem que confere à moralizaçáo o status de conselho. A centralidade dessas narrativas na mensagem e no herói provoca o imaginário à continuidade da história pela ambiguidade que se abre no leitor, e não apenas nos fatos narrados. Nos contos de fadas, a voz autoritária do adulto sobre a criança se dilui nessa ambiguidade que se instaura, pois vencer o mito implica também a libertação do narrador cúmplice e partícipe de uma infância da própria humanidade.

Foi a partir do século XX, com a realizaçáo de pesquisas de cunho psicanalítico e pedagógico voltadas para a criança, que a linguagem dos textos infantis se desloca da mensagem para fazer prevalecer a função pedagógica. A literatura infantil passa, então, a ser confundida com a pedagogia. Dessa forma, a informação, e não exatamente o conselho, passa a ser predominante. $\mathrm{O}$ reflexo dessa concepçáo no texto aparece na forma como a narrativa é conduzida: é a voz de um adulto, que sabe e conhece, que transmite uma mensagem para um menor que recebe, compreende e copia.

Benjamin lança um olhar crítico para essas produçóes, que evidenciam a intenção de moralização e disciplinarização das crianças, e que apresentam um distanciamento do que as crianças são capazes de problematizar perante o mundo: 
Trata-se de um preconceito segundo o qual as crianças são seres tão diferentes de nós, com uma existência tão incomensurável à nossa, que precisamos ser particularmente inventivos se quisermos distraí-las. No entanto, nada é mais ocioso que a tentativa febril de produzir objetos - material ilustrativo, brinquedos ou livros - supostamente apropriados às crianças. [...] Em seu preconceito, eles não veem que a terra está cheia de substâncias puras e infalsificáveis, capazes de despertar a atenção infantil (Benjamin, I993a, p. 237).

$\mathrm{O}$ autor considera ociosa a tentativa de os adultos produzirem objetos destinados às crianças conforme sua visão adultocêntrica, pois as crianças, diante das produçôes culturais, criam, alteram e transformam. Para Benjamin, as cores, a atmosfera onírica dos livros, por exemplo, convidam as crianças a um diálogo para além do texto. Assim, ficam mais envolvidas e interessadas com o fantástico, com as ilustrações, do que propriamente com a função moralizante dos textos. Benjamim faz uma critica ácida aos pedagogos que têm como tarefa inculcar em crianças e jovens princípios e valores imperativos, questionando a pedagogia burguesa ao afirmar: "a burguesia vê sua prole enquanto herdeiros; mas, aos deserdados, enquanto apoio, vingadores ou libertadores" (Benjamin, I984, p. 89).

Para Benjamin (I993a), a literatura produzida em sua época era "uma criação sem raízes, por onde circula uma seiva melancólica, que nasceu do solo de um preconceito inteiramente moderno" (p. 237), preconceito relacionado à concepção de infância baseada na falta, na incompletude, na minoridade, na imaturidade, na improdutividade, na dependência em relação ao adulto. No entanto, tal concepção também foi questionada ao longo dos anos que nos separam de Benjamin.

São muitas as tensôes e as contradiçôes subjacentes às obras destinadas às crianças. Hoje, há um número significativo de livros 
que instigam as crianças, fazendo com que se desloquem, se surpreendam e se emocionem. Existem autores, ilustradores e editores que apostam na capacidade das crianças, que sabem quanto elas são indomáveis em sua forma peculiar de significar os textos; que estáo atentos à qualidade do texto verbal, das ilustraçôes, da abordagem dialógica dos temas que perpassam a vida, e não apenas a um suposto universo infantil. Tais autores conseguem colocar no mercado obras que são fruto de uma visão crítica de infância e de luta, na contramão de um empobrecimento da linguagem. Todavia, há aqueles que insistem em manter a tutela e em não fazer da tradição algo produtivo e transformador. Há outros ainda que se rendem às facilidades da cultura de massa, ao empobrecimento da experiência humana e à alienação de uma linguagem rasa e das abordagens banais.

A escolarização, que se instituiu como um direito de todas as crianças à educação, foi e tem sido um nicho do mercado editorial que produz toda a sorte de livros infantis: didáticos, informativos, não ficcionais, de autoajuda, brinquedo, literários, entre outros. Muitas são as categorias possíveis e seus hibridismos. Neste texto, nossa proposta consiste em discutir os livros infantis literários. Mas, em que pesem a extensão dessa categoria e as divergências de concepçáo, para tecer nosso ponto de vista, tomamos como pressuposto a literatura como arte, independentemente da classificação - se infantil ou não - e as teorias de Bakhtin e de seu círculo (Voloshínov, 1926), bem como as de Vigostski (200I), que também abordam a literatura nessa perspectiva.

Bakhtin (1926) - e o Círculo de Bakhtin/Voloshínov - entende a arte como um elemento eminentemente social:

O meio social extra-artístico, afetando de fora a arte, encontra resposta direta e intrínseca dentro dela. Não se trata de um elemento estranho afetando outro, mas de uma formação so- 
cial, o estético, tal como o jurídico ou o cognitivo, é apenas uma variedade do social (p. I).

$\mathrm{O}$ autor faz uma crítica a dois pontos de vista.

$\mathrm{O}$ primeiro, que define a fetichização da obra artística como artefato, uma atitude que restringe a obra de arte a si própria. No caso da literatura, o verbal não como um fenômeno sociológico, mas como um fenômeno linguístico abstrato, compreendido independentemente da situação social que o engendra.

$\mathrm{O}$ segundo, que restringe a arte ao estudo da psique do criador ou do contemplador, resumindo-a às experiências da pessoa contemplando/lendo ou da pessoa criando/escrevendo.

Assim, para o autor, ambos os pontos de vista pecam pela tentativa de descobrir o todo na parte: "O artístico é uma forma especial de inter-relação entre criador e contemplador fixada em uma obra de arte" (Idem, p. 3). A arte se torna arte na interação entre criador e contemplador; fora disso, é um mero artefato ou exercício linguístico.

Bakhtin (1926) - e o Círculo de Bakhtin/Voloshínov — sustenta a ideia de que a forma de um enunciado artístico é a expressão direta de avaliaçôes sociais. Julgamentos de valor determinam a seleção de palavras do autor, bem como a respectiva recepção dessa seleção por ouvinte/leitor. Para o autor, cada expressão selecionada é um ato avaliativo orientado em duas direçôes — na direção do ouvinte e na direção do herói: "Ouvinte e herói são participantes constantes do evento criativo, o qual não deixa de ser, nem por um instante, um evento de comunicação viva envolvendo todos os três" (Idem, p. II). Assim, embora a forma esteja fixada num material, a significação da forma tem relação não com o material, mas com o conteúdo. A seleção do conteúdo e a seleção da forma constituem um ato único, estabelecendo a posição básica do criador; e, nesse ato, uma e a mes- 
ma avaliação social encontra expressão. $\mathrm{O}$ artista, pela mediação da forma artística, assume posiçáo ativa no que diz respeito ao conteúdo. Nesse sentido, forma e conteúdo são indissociáveis e marcam a posição do criador. Assim, autor, herói e ouvinte/leitor são elementos constitutivos da obra, determinantes da forma e do estilo desde o seu interior.

O ouvinte/leitor é um participante imanente, um fator intrínseco da obra, e não coincide com o público-leitor, localizado fora da obra, cujos gostos e exigências podem ser conscientemente levados em conta. No entanto, para Bakhtin, "se o fato de levar conscientemente em conta o público-leitor vem ocupar uma posição de alguma importância na criatividade do poeta, essa criatividade inevitavelmente perde sua pureza artística e se degrada a um nível social mais baixo" (Idem, p. I2). O ouvinte/leitor não pode ser confundido com uma pessoa real. O interesse externo do autor aponta para a perda do ouvinte/leitor imanente e para a cisáo do todo social, determinando, intrinsecamente, os julgamentos de valor e a forma artística de seus enunciados poéticos. Para o filósofo da linguagem, a forma de um enunciado artístico é determinada pelos seguintes elementos: o valor hierárquico do herói ou evento funcionando como o conteúdo do enunciado; seu grau de proximidade com o autor; e o ouvinte e sua inter-relaçáo com o autor, de um lado, e com o herói, de outro. A concepçáo de infância do autor é, portanto, fator determinante para a obra. $\mathrm{Na} \mathrm{li-}$ teratura infantil, são considerados autores o escritor, o ilustrador e o designer gráfico, pois todos eles imprimem suas marcas na articulação entre os discursos verbal e visual.

A concepção bakhtiniana de arte provoca, assim, algumas questôes quanto às obras de literatura infantil. Ao analisar cada produção, cabe indagar: como se estabelece a relação entre autores, herói e ouvinte/leitor? Com que julgamento de valor os autores constroem o herói em correlação com o ouvinte/leitor infantil? 
Vigotski (200I) tece algumas considerações sobre a arte que dialogam com as discussóes de Bakhtin. Seu enfoque estético tem fundamento psicossocial, ou seja, a arte deve combinar as vivências individuais com a recepção do produto estético percebido como produto social e cultural. Bezerra (200I), na introdução do livro Psicologia da arte, de Vigotski, afirma: "A arte é o social em nós. Mesmo que o seu efeito se registre em um indivíduo à parte, isso não nos autoriza a afirmar que as raízes e a essência da arte sejam individuais, assim como seria ingênuo imaginar o social apenas como coletivo "(p. xii). Além dessa dimensão social, Vigotski destaca a importância da emoção na arte tanto na produção da obra como na apreciação. A arte deve ser capaz de abordar emoçôes contraditórias, de modo a construir um deslocamento, um "curto-circuito emocional" no apreciador.

Vigotski e Bakhtin entendem o artístico nas inter-relações entre criador, contemplador e obra. Cada um desses três elementos é constitutivamente social. O social expresso na própria obra e no que ela desencadeia no outro e o social constitutivo tanto do artista-criador como do contemplador-apreciador: sujeitos históricos, socialmente situados.

\subsection{Literatura infantil: artes em convergência}

A literatura, como toda arte, como assinala textualmente o poeta Fernando Pessoa, é a "confissão de que a vida não basta". E a vida não basta para adultos e crianças. Partimos, então, do seguinte ponto: tratar a literatura infantil contemporânea naquilo que "não basta".

Elegemos uma obra para tecer nossos argumentos, entendendo-a como mônada, parte que dialeticamente contém o todo. Uma obra de literatura infantil que, em sua singularidade, reflete "tudo em si e está refletida em tudo" - um elemento cultural que 
participa da cultura humana (Bakhtin, I998, s.p.). Trata-se do livro Raposa, de Margaret Wild, com ilustraçóes de Ron Brooks e tradução de Gilda Aquino.

A escolha para a análise dessa obra decorreu dos seguintes critérios: i) qualidade reconhecida por um grupo de especialistas recebeu o Prêmio da Fundaçáo Nacional do Livro Infantil e Juvenil na categoria tradução e adaptação em 2006 e foi selecionada pelo PNBE-2006 para os anos iniciais do ensino fundamental; ii) pertence a um gênero clássico - a fábula - com um viés contemporâneo, o que favorece comparaçóes e referências; iii) é um livro classificado como picturebook, ou livro ilustrado, cuja principal característica é a interdiscursividade que se estabelece entre o discurso verbal e o visual. Nesse contexto, embora Raposa não seja o tipo de livro que surgiu apenas na atualidade, tem estado cada vez mais presente nas produçôes contemporâneas; iv) há registros de evento de pesquisa de campo realizada em uma turma de crianças de 5 a 6 anos, com a leitura desse livro, que compóe o corpus de um dos estudos de caso da pesquisa "Infância, linguagem, escola: a leitura literária em questão", por nós coordenada e que resultou na dissertação de mestrado de Soares (20I4).

Nesse livro, como em muitos outros do gênero, as artes da palavra e a arte visual são interdependentes. Dessa maneira, é necessário ler e ver, pois tanto uma coisa como outra dizem algo. E a narrativa é conduzida pelas duas linguagens simultaneamente. Para Belmiro (20I2), é preciso "superar a dicotomia ver versus ler, adicionando ao ver o estatuto de ler alguma coisa, e, ao ler, as condiçóes de poder ver alguma coisa. O que nos une é o dizer, e isso solicita uma discursividade que recupera a presença dos interlocutores e seus atos de fala" (p. 127).

Calvino (1990), ao discutir o futuro da literatura no milênio em que vivemos, confia em que "há coisas que só a literatura com seus meios específicos nos pode dar" (p. II). Entendemos 
que esses meios específicos se articulam às considerações de Candido (20II), ao conceber a literatura como direito de todos e um bem incompressível, ou seja, indispensável ao ser humano. Mas quais seriam as qualidades, as especificidades da literatura? Calvino apresenta seis propostas que estendemos à literatura sem adjetivos: leveza, rapidez, exatidão, visibilidade, multiplicidade e consistência.

$\mathrm{Na}$ leveza, entre outras imagens, mitos e lendas, Calvino (I990) apresenta "o salto ágil e imprevisto do poeta-filósofo que sobreleva o peso do mundo, demonstrando que sua gravidade detém o segredo da leveza" (p. 34). A literatura daria a possibilidade do voo, não como devaneio ou fuga, mas como libertação. Seria a possibilidade de fabulação, que Candido (2OII) considera uma "manifestação universal de todos os homens em todos os tempos" (p. I76). Em outras palavras, seria na vigília o que o sonho é no sono, indispensável à pessoa humana.

A leveza do voo em literatura infantil, contudo, é frequentemente entendida como falta de consistência e densidade. Visão simplificada e/ou adocicada dos dramas humanos, como se a criança não participasse deles ou não os sofresse na própria pele. A leveza é o contraponto do peso. A literatura, ao trazer ao leitor questóes da vida, permite o encontro do eu com o outro, numa alteridade constitutiva. Nessa via, a literatura proporcionaria ao sujeito uma ampliação de sua compreensão do mundo, de si mesmo e do outro. Passamos, então, ao diálogo com a obra eleita para análise.

Raposa é uma fábula contemporânea que discute lealdade, amizade, inveja e traição. Após um incêndio na floresta, Cão, um cachorro cego de um olho, salva Gralha, que teve a asa queimada. Ambos estreitam seus laços afetivos e passam a se complementar mutuamente: Cão torna-se as asas de Gralha, e esta, os olhos de Cão. Mas, "depois das chuvas, quando os brotos aparecem por 
toda parte, uma raposa surge na mata. Raposa com seus olhos ferinos e pelo grosso avermelhado. Ela se esgueira entre as árvores como uma língua de fogo, e Gralha treme de medo" (Wild, 2005, p. I5).

A raposa reúne-se eles. Entretanto, está sempre à espreita, e "seu cheiro parece penetrar na caverna - um cheiro de raiva, inveja e solidáo" (Idem, p. I8). Ardilosa, Raposa tenta gradativamente convencer Gralha a dar um passeio, montada em suas costas, e, de maneira sutil, tenta arruinar a relação de carinho e afeto entre Cão e Gralha.

Nesse livro, a leveza é dada pela estética provocada pela articulação entre o verbal e o visual. A estética provoca o deslocamento da dureza da inveja e da traição, possibilitando o "salto do peso do mundo".

As ilustraçôes transbordam de uma página a outra, e as texturas, cores e traços criam ritmos visuais. Os tons terrosos, que vão do laranja ao marrom, predominam e sugerem o clima de excitação e perigo da narrativa. As palavras se integram às imagens e deslocam-se de um lugar a outro, potencializando a ideia de movimento e aumentando o poder das sequências e, com isso, o leitor é obrigado a mudar a posiçáo do livro (Soares, 20I4, p. I3I).

Como salientado, a obra apresenta intensa interlocução entre o discurso verbal e o visual. As cores, os traços, as linhas, a técnica eleita pelo ilustrador, as letras, sua tipologia e suas diferentes posiçôes e tamanhos nas páginas, tudo isso forma um conjunto integrado que se dá a ler e que também vai propondo outra forma de o leitor se posicionar. Há um jogo de virar o livro e/ou de virar o corpo para ler o texto escrito, que é mais um elemento visual, pois se encontra em diferentes posiçôes da página. Esse jogo, de algu- 
ma forma, pelo movimento do leitor ao buscar o texto, cria outra cadência narrativa.

A narrativa e os diálogos entre os animais da história são concisos, com frases curtas, que deixam espaço para pausa, reflexão e abertura, a fim de que o leitor reflita sobre os acontecimentos de cada página. Os nomes próprios dos personagens são seus nomes comuns: o Cão, a Gralha e a Raposa, como nas fábulas tradicionais. São também comuns as características apresentadas nas próprias açóes dos personagens:

Gralha tenta avisar Cão sobre Raposa:

— Ela não tem amigos, não ama ninguém.

Mas Cão responde:

— Deixa pra lá! Não se preocupe!

Naquela noite, enquanto Cão dormia, Raposa sussurrou para Gralha:

- Eu corro mais depressa do que Cão. Mais depressa do que o vento. Deixe Cão e venha comigo.

Gralha respondeu:

- Nunca deixarei Cáo. Sou o olho que lhe falta e ele é as minhas asas (Wild, 2005, pp. 20-I).

Em cada página, as cenas das ilustraçôes, com os personagens e outros elementos, formam uma composição que também é aberta. Há figuras e fundo, espaços vazios e espaços preenchidos com grafismos. As duas folhas se integram, ora são duas, ora um único palco. A palheta de cores a cada cena varia em tons da mesma nota, com pequenos destaques que se destacam. Todos esses recursos de composição de palavras e imagens apresentam, de forma precisa, a temática abordada. $\mathrm{Na}$ exatidão da forma, os autores imprimem o conteúdo: os sentimentos humanos, que, pela voz dos animais, concentram momentos afetivos e criam um iso- 
lamento da realidade necessário e indispensável à impressão estética. Para Vigotski (200I, p. I20), "a convencionalidade desses heróis garante o isolamento necessário para o efeito artístico", e nós vamos encontrar essa mesma propriedade posteriormente, em todas os personagens da literatura.

Calvino apresenta a rapidez como mais uma proposta da literatura. A rapidez diz respeito ao tempo narrativo, tempo de espera do que se sucederá, tempo do discorrer, da velocidade que impóe ao pensamento, provocada pela concisão de gêneros e estilos. $O$ tempo presente na palavra organizada que não é cronológico, mas apresenta sucessão, simultaneidade e ordem. Para Candido (20II), "quer percebamos claramente ou não, o caráter de coisa organizada da obra literária torna-se um fator que nos deixa mais capazes de ordenar a nossa própria mente e sentimentos, e, em consequência, mais capazes em organizar a visão que temos do mundo" (p. I79). E esse poder organizador se efetiva pelas características que Calvino apresenta como a exatidáo:

I) um projeto de obra bem definido e calculado; 2) a evocação de imagens visuais nítidas, incisivas, memoráveis [...]; 3) uma linguagem que seja a mais precisa possível como léxico e em sua capacidade de traduzir as nuanças do pensamento e da imaginaçáo (Idem, p. 7I).

Tirar as palavras do nada e dispô-las como um todo organizado seria, para Candido (20II, p. I79), o primeiro nível humanizador da literatura. A maneira como o conteúdo é organizado impressiona, faz pensar e amplia as formas de ver e de sentir.

Voltando ao livro Raposa, depois de convencer a Gralha,

Raposa corre pelas colinas, por planícies poeirentas e pelas caatingas, até chegar ao deserto vermelho e quente. Ela para de repente. 
Entre ambos, só há silêncio. Ninguém se move e ninguém diz nada. Então Raposa sacode Gralha de cima de suas costas, como se tirasse uma pulga, e sai andando. Ela se vira, olha para Gralha e diz: "Agora você e Cão saberão o que é solidão". E então ela some. Em meio ao silêncio, Gralha ouve um grito ao longe. Ela não sabe se é um grito de vitória ou de desespero. Gralha junta suas penas, que planam no ar quente. Ela se sente queimando no meio do nada. Seria tão fácil morrer aqui no deserto. Mas, então, Gralha pensa em Cão acordando, descobrindo que ela se foi. E, lentamente, cambaleando, ela começa seu longo caminho de volta (Wild, 2005, pp. 27-34).

Uma fábula que deixa a moral implícita. Faz imaginar um final. O destino da Gralha e suas possibilidades. O final aberto ao pensamento das crianças. A convergência entre ciência, arte e vida traz a unidade de sentido (Bakhtin, 2003). Crianças que não são subestimadas, que são chamadas a viver e a pensar a vida e suas agruras.

Calvino (1990) relaciona a visibilidade à imaginação e à capacidade que a literatura tem de evocar imagens e nos provocar. $\mathrm{O}$ autor distingue dois tipos de processo imaginativo: "O que parte da palavra para chegar à imagem visiva e o que parte da imagem visiva para chegar à expressão verbal" (p. 99). O livro de literatura infantil apresenta esses dois processos simultaneamente, em especial quando deixa espaços indeterminados, inacabados, abertos ao leitor, tanto pela via palavra como pela via da ilustraçáo. As artes têm essa capacidade de nos fazer ver o que, com frequência, não percebemos ou percebemos sob outro ângulo. A arte dá a ver o invisível e o imperceptível.

Se, para Candido (20II), há uma necessidade inerente ao homem de representar a própria vida de forma distinta da realidade cotidiana, para Vigotski (2009), "a imaginação não é um divertimento ocioso da mente, uma atividade suspensa no ar, mas uma 
função vital necessária” (p. 20). A atividade criadora humana é toda e qualquer ação em que se cria algo novo, independentemente de ser mental ou material.

Vigotski afirma que a imaginação é a base de toda e qualquer atividade criadora, sendo comum a todos os homens; ela está por toda parte e em todo lugar, sempre que o sujeito "imagina, combina, modifica e cria algo novo, mesmo que esse novo se pareça com um grãozinho, se comparado às criaçôes dos gênios" (Idem, p. I5). A capacidade imaginativa é também humanizadora, na medida em que nos faz pensar sobre o novo, o possível e até mesmo a utopia. Soares (20I4, p. 135) relata um diálogo que se sucedeu à leitura do livro:

Após a leitura, um menino sussurra:

José Renato: Eu queria que a raposa fosse do bem.

A professora reproduz a enunciaçáo do menino ao grupo:

Professora: Olha, o José Renato disse que queria que a raposa fosse do bem. E vocês, o que acham?

Clarice: Eu acho que ela não era do bem.

Maria Luiza: É, ela era má.

A conversa termina aí, pois a professora de Informática espera pela turma na porta da sala. Apesar disso, duas crianças disputam o livro. Uma delas desiste e acompanha o grupo, a outra senta-se a uma mesa e folheia as páginas do livro. Ela passa as páginas rapidamente e parece procurar por alguma parte da história. Ao se deparar com a imagem da Gralha em cima da Raposa, para, observa... E diz, olhando na minha direção:

Luana: Viu como ela é má?

Depois, fecha o livro rápido e sai da sala para juntar-se ao grupo (Caderno de campo, 21/5/2013). 
Essa fala traz a perplexidade das crianças diante da maldade do personagem, levando Luana a buscar a cena da Gralha nas costas da Raposa para confirmar: "Viu como ela é má?". A maldade ali de olhos reluzentes, amedrontando, mas que se vai ao fechar a página do livro. $\mathrm{O}$ arrebatamento da criança pelo ficcional, mas também sua certeza de que aquela raposa má à espreita pode desaparecer no virar das páginas.

\subsection{Algumas Consideraçóes}

Bakhtin (2003) considera que a arte "me dá a possibilidade de vivenciar, em vez de uma, várias vidas, e assim enriquecer a experiência de minha vida real, comungar de dentro com outra vida em prol desta, em prol de sua significação vital" (p. 74).

Esse enriquecimento também humaniza. Viver outra vida é viver uma rede de possíveis. Sair de si, chegar mais perto do outro. Ser um e muitos. Multiplicidade. Mais uma proposta de Calvino para a literatura. A multiplicidade é parte e exigência do contemporâneo. E, para dispensar os limites, depende dos processos imaginativos de cada um. Esse inacabamento é justamente o que abre as possibilidades do múltiplo: multiplicidade de gêneros, abordagens, estilos, suportes. Se há uma estrutura que sustenta a literatura, há uma arquitetura que recria, reinventa e surpreende.

Ao contrário da natureza, o mundo da cultura é produto da criação humana, e é exatamente essa atividade criativa que possibilita ao homem náo ser um mero reprodutor do passado, mas alguém capaz de alterar o curso do tempo contínuo e escovar a história a contrapelo (Benjamin, I993a). E contamos com cada nova geração para esse projeto. É a consistência, a palestra que náo pode ser finalizada, que fecha as propostas de Calvino para a literatura. Talvez boa parte daquilo a que nos referimos como proposta da literatura, do cinema e de outras artes também possibi- 
lite isso. Entretanto, a literatura destinada a crianças, dentro dos novos paradigmas de infância e literatura, pode ser um espaço de formação e liberdade, de conhecimento de si, do outro e do mundo, de deslocamentos e ampliaçóes, de sensibilidade e humanização. Tudo isso dá mais sentido e consistência à existência. Como diz Bakhtin (2003), "o poeta deve compreender que sua poesia tem culpa pela prosa trivial da vida, e é bom que o homem da vida saiba que sua falta de exigência e a falta de seriedade das suas questóes vitais respondem pela esterilidade da arte" (p. xxxiv).

\section{Referências}

ADORNO, Theodor W. e HORKHEIMER, Max. Dialética do esclarecimento. Rio de Janeiro: Jorge Zahar Editor, 1985.

BAKHTIN, Mikail (Volochinov). Marxismo e filosofia da linguagem. São Paulo: Hucitec, 1992.

- Questôes de literatura e de estética. Sáo Paulo: Unesp,I998.

. Estética da criação verbal. Trad. de Paulo Bezerra. 4 ed. São Paulo: Martins Fontes, 2003.

BARROS. Manuel de. Memórias inventadas: a infância. São Paulo: Planeta, 2003.

BENJAMIN, Walter. Obras escolbidas I: magia e técnica, arte e politica. São Paulo: Brasiliense, 1993a.

. Obras escolhidas II: rua de mão única. São Paulo: Brasiliense, 1993b.

CALVINO, Italo. Seis propostas para o próximo milênio. São Paulo: Companhia das Letras, 1990.

CANDIDO, Antônio. "O direito à literatura". Vários escritos. Rio de Janeiro: Ouro sobre Azul, 2oIr.

CASTRO, Lúcia Rabello de. O futuro da infância e outros escritos. Rio de Janeiro: 7 Letras, 2013 .

COMPAGNON, Antoine. O demônio da teoria. 2 ed. Belo Horizonte: Ed. UFMG, 20IO. 
Literatura para quê? Belo Horizonte: Ed. UFMG, 2009.

CORSARO, Willian. Sociologia da infância. Porto Alegre: Artmed, 201.

EAGLETON, Terry. Teoria da literatura: uma introdução. São Paulo: Martins Fontes, 2006.

MEIRELES, Cecília. Problemas de literatura infantil. Rio de Janeiro: Nova Fronteira, 1984.

POSTAMAN, Neil. O desaparecimento da infância. Rio de Janeiro: Graphia, I999.

SARMENTO, Manuel. "A reinvenção do ofício de criança e de aluno". Atos de pesquisa em educação, Furb, v 6, n. 3, pp. 58I-602, $201 \mathrm{I}$.

SOARES, Carolina Monteiro. Viagens literárias por palavras e imagens: o livro ilustrado e a leitura na escola: uma experiência na educaçáo infantil do Colégio Pedro II (dissertação). UFRJ, 2014.

SOUZA, Solange Jobim e. "Re-significando a psicologia do desenvolvimento: uma contribuição crítica à pesquisa da infância”. In KRAMER e LEITE (orgs.). Fios e desafios da pesquisa. Campinas: Papirus, I996, pp. 39-55.

VIGOTSKI, Lev Semenovitch. Psicologia da arte. Trad. de Paulo Bezerra. São Paulo: Martins Fontes, 200I. . Imaginação e criação na infância. Trad. de Zoia Prestes. São Paulo: Ática, 2009. 